\title{
Diagnostic testing for SARS-CoV-2
}

\author{
Carl Boodman MD, Philippe Lagacé-Wiens MD DTM\&H, Jared Bullard MD
}

Cite as: CMAJ 2020 June 29;192:E713. doi: 10.1503/cmaj.200858; early-released June 3, 2020

1

Test sensitivity depends on timing of sample collection

Testing for severe acute respiratory syndrome coronavirus 2 (SARSCoV-2) relies on reverse transcription polymerase chain reaction (RTPCR), which amplifies SARS-CoV-2 genetic material. ${ }^{1}$ Nasopharyngeal or oropharyngeal RT-PCR sensitivity is highest when performed early after symptom onset. ${ }^{2-4}$

\section{Test sensitivity varies according to specimen type and disease severity}

In patients who progress to have lower respiratory tract disease, the sensitivity of nasopharyngeal and oropharyngeal RT-PCR declines and the yield from lower respiratory tract samples, such as samples taken from sputum, endotracheal tube and bronchoalveolar lavage, increases. ${ }^{4}$ Lower respiratory tract samples may reveal a positive result when nasopharyngeal and oropharyngeal sampling has not.

\section{Test positivity does not always entail infectivity}

Although RT-PCR viral loads slowly decline as patients recover, laboratories report a "yes/no" result and do not regularly report viral load. Results of RT-PCR may remain positive for many weeks after the clinical disease has resolved. These late positive results, after symptom resolution and 10 days or more after symptom onset, are unlikely to be associated with replicating virus on cell culture and are unlikely to be infectious. ${ }^{4}$

Point-of-care testing provides rapid diagnosis but is limited by "low throughput"

Health Canada has approved certain point-of-care testing platforms, and many others remain under regulatory review. ${ }^{5}$ Current point-of-care testing has decreased turnaround time $(<1 \mathrm{hr})$ but is limited by its inability to test many samples simultaneously, a phenomenon known as "low throughput."

\section{Positive serology does not equate with lifelong immunity}

Serologic tests measure immunoglobulin antibodies, showing previous exposure to a pathogen or its genetic kin. Although serology is often used as an imperfect surrogate of immunity, serology does not directly assess a patient's ability to neutralize a pathogen. ${ }^{4}$ Also, the duration of antibody response to SARS-CoV-2 remains unknown. Widespread serologic testing may assess seroprevalence but will not provide a clear determination of long-standing immunity.

\section{References}

1. Corman VM, Landt O, Kaiser M, et al. Detection of 2019 nove coronavirus (2019-nCoV) by real-time RT-PCR. Euro Surveill 2020;25:2000045. doi: 10.2807/1560-7917.ES.2020.25.3.2000045.

2. He X, Lau EHY, Wu P, et al. Temporal dynamics in viral shedding and transmissibility of COVID-19. Nat Med 2020;26:672-5.

3. Zou L, Ruan F, Huang M, et al. SARS-CoV-2 viral load in upper respiratory specimens of infected patients. N Engl J Med 2020;382:1177-9. doi: 10.1056/NEJMc2001737.

4. Wölfel R, Corman VM, Guggemos W, et al. Virological assessment of hospitalized patients with COVID-2019. Nature 2020;581:465-9.

5. Testing devices for use against coronavirus (COVID-19): list of authorized devices. Ottawa: Health Canada; modified 2020 May 13. Available: www.canada.ca/en/health-canada/services /drugs-health-products/medical-devices/covid-19/diagnostic -devices-authorized.html (accessed 2020 May 24).

\section{Competing interests: None declared.}

This article has been peer reviewed.

Affiliations: Section of Infectious Diseases, Department of Internal Medicine (Boodman), Department of Medical Microbiology and Infectious Diseases Medicine (Boodman, Lagacé-Wiens) and Department of Pediatrics and Child Health (Bullard), Max Rady College of Medicine University of Manitoba; Shared Health (Lagacé-Wiens); Cadham Provincial Laboratory (Bullard), Winnipeg, Man.

Correspondence to: Carl Boodman, boodmanc@myumanitoba.ca

CMAJ invites submissions to "Five things to know about ..." Submit manuscripts online at http://mc. manuscriptcentral.com/cmaj 